\title{
Building the Capacity of Farmer Based Organisation for Sustainable Rice Farming in Northern Ghana
}

\author{
Quaye Wilhemina (Corresponding author), Yawson Ivy, Manful John Tawiah \& Gayin Joseph \\ CSIR - Food Research Institute P. O. Box M20 Accra, Ghana \\ Tel: 233-20-813-2401 E-mail: quayewilhemina@yahoo.com
}

The Food Security and Rice Producers Organisation Project (FSRPOP) was sponsored by French Embassy in Ghana

\begin{abstract}
This study assessed the perceptions of stakeholders concerning implementation activities of a Food Security and Rice Producers Organisation Project (FSRPOP) in Northern Ghana. The project aimed at building the capacities of farmer based organisations (FBOs) to assist rice farmers access credit, organise production inputs and improve market access. The study results showed that although access to input supply and production credit improved, enhancing farmers' marketing capacity was not successful. The management capacity of the FBOs was weak in performing more complex administrative issues and market facilitating roles. Timely provision of production inputs, use of custom based processing and credit inventory system for maximum profit were some of the lessons learnt. Facilitation of farmer medium scale buyer linkages and the development of lessons-based action plan for change with beneficiaries were recommended
\end{abstract}

Keywords: Stakeholders, Rice, Development, Sustainability, Ghana

\section{Introduction}

Rice is a commodity of strategic importance to Africa and has become the fastest-growing food source to both rich and poor households (Nwanze et al 2006). Rice has become a major staple in Ghana in recent times although the crop has been cultivated for several years. It is an important food for both rural and urban dwellers, and is gradually taking over from traditional, mainly root and cereal crops, staples (Quaye et al 2000). Factors affecting increased consumption of rice have been identified to include rising incomes, trade liberalization, extensive promotion and effective marketing strategies of rice importers and ease of cooking among others (Oteng 1997; Day et al 1997; Tomlin's et al 2007).

Consumption of milled rice in Ghana went up from below 100,000 Mt to over 600,000Mt between 1985 and 2003 (Tomlin's et al 2005). Unfortunately, the sharp rise in consumption has not impacted positively on the local rice production levels since a significant proportion of rice consumed is imported (Quaye 2007). Rice is cultivated in four main ecological areas in Ghana. These include rainfed upland (in Northern Ghana), rainfed lowland (Northern Ghana), and Inland swamp-inland valley of central Ghana and irrigated - Northern and Southern Ghana. The major challenge faced by local farmers is the high cost of production since most of the agricultural inputs are imported (Khor, 2006). Other constraints limiting production include lack of access to credit, shortage of water, pests, diseases, unavailability of suitable varieties, low quality of locally processed rice and inefficient markets for inputs and produce (Furuya and Sakurai, 2003; Adolph and Chancellor, 2006).

It is against this background that development efforts to revamp the rice industry in Ghana have become crucial in recent times. One such effort is the lowland Rice Development Project (LRDP) and its extension, Food Security and Rice Producers Organization Project (FSRPOP). The LRDP was implemented in the Northern region of Ghana in 1999 -2003 and the extension (FSRPOP) in 2003-2007. The first component (LRDP) aimed at demonstrating the viability of rice production in the treated lowland of the Northern Region. The second component (FSRPOP) aimed at sustaining the rice intensive cropping scheme developed under LRDP. This was done by building the capacities of farmer based organisations (FBOs) to fulfill some of the tasks ensured previously by LRDP, such as organise access to inputs and tractor services, monitor cropping activities, manage and sustain their collective structures (storage and water), access and manage credit as well as organise marketing of paddy. An APEX body (named Northern Region Intensive Lowland Rice Farmers' Cooperative Union -NILRIFACU) representing all FBOs at the regional level was formed to act as a mouth-piece and effectively negotiate with stakeholders including input suppliers, tractor owners, banks, rice processors and traders on behalf of the farmers 
To alleviate the marketing problems faced by rice farmers in Ghana, FSRPOP project implemented a Parboiled Rice Quality Improvement Programme in the Northern Region where rice production is predominant with the following objectives:

- To produce on a pilot-basis in 4 selected communities located around Tamale (The regional capital of the Northern region of Ghana), high quality parboiled and milled rice. This is done using improved equipment and designing appropriate programmes of schedules or list of good practices for small-scale rice producers and processors, with close field supervision and technical support.

- Under the FSRPOP marketing support programme, the high quality parboiled and milled rice produced was then to be bought by the APEX bagged in 3-kg sachets, branded, advertised and displayed nationwide at a price equivalent to the Asian imported rice. Extra incomes generated by the sale of this rice were to be distributed equitably among the different stakeholders (Farmers, Processors and Millers) and therefore constituted incentives to follow the designed programmes of schedules.

\section{Study Objectives/purpose}

Specific objectives of this study were as follows:

- $\quad$ to investigate stakeholders' perceptions of project performance

- $\quad$ To document lessons learnt from the implementation strategies

- $\quad$ To make recommendations for improvement in project performance

\section{Methodology/Study design}

Qualitative research methodology was employed in the field survey to address study objectives. This was complemented with review of literature on FBOs. Using participatory appraisal techniques semi structured interviews, group discussions and informal interactions were conducted among the different stakeholders participating in the Food Security and Rice Producers Organisation Project (FSRPOP) in Northern Ghana.

\subsection{Sampling}

The sampling frame was the FSRPOP beneficiaries. This included four farmer groups selected from Sakapaligu, Kumbungu, Kuoku and Gbalahi communities in Northern Region; two processor groups and millers from Tamale and Kumbumgu and an APEX body with representatives from all farmer groups mandated to oversee the programme. The target communities were selected based on level of rice production and processing activities as well as involvement in the lowland Rice Development Project (LRDP) implemented in 1999 - 2003 in the same region.

The project covered 100 farmers in the four groups, 10 processors and 2 millers; which constituted the sampling frame for this study. From the sample frame, a total of 82 stakeholders comprising of 70 farmers in the four groups, 10 processors and 2 millers were interviewed. In addition, the APEX body consisting of farmer representatives and community leaders was also interviewed

\subsection{Data collection}

Data collection instruments were semi-structured questionnaire and interview guide for interviews and focus group discussions respectively. The semi-structured questionnaire which comprised several open-ended questions allowed respondents a wide range of options and encouraged them to express their views on the project implementation strategies. Respondents were tasked to evaluate project performance with respect to targets and achievements as well as expected impact on beneficiaries. Focus group discussions were useful for triangulation and consensus building on key issues relating to project output indicators (Borgatti 1999; Denzin and Lincoln 2005).

\subsection{Data Processing and Analysis}

Statistical Package for Social Scientist (SPSS) version 16.0 was used for data analysis. The data was cleaned and processed. SPSS analysis outputs were then exported into a well designed Excel Template to generate indicator results and relevant inferences made.

A GAP analysis was employed (Timsina et al 2004). This sought to identify programme interventions, gauge set targets against achievements, and the variance noted. The assessment team also interacted with project monitoring task team and a meeting was also held with the French Embassy representative coordinating the FSRPOP project.

\section{Findings}

\subsection{Intervention Strategies and GAP Analysis}

As indicated in the methodology, the GAP analysis identifies programme interventions, gauges set targets against achievements, and the variance noted. Generally, the project provided support to FBOs to strengthen their capabilities. The purpose was to enable the FBOs relate better with the financial institutions improving on farmer access to credit, 
organise production inputs and also improve on access to market. In addition to technical support the FBOs were provided with logistics to facilitate the movement and operations of its officials. The analysis was done at various levels including farmer, processor, miller and APEX.

\subsubsection{Farmer}

Some of the constraints facing rice farmers identified under the lowland Rice Development Project (LRDP) were poor farming practices, lack of capital, high cost of production inputs such as fertilizer and seed, lack of access to market as well as lack of price incentive to produce high quality paddy. At the farmer level, the FSRPOP programme sought to remove these constraints especially lack of access to market in order to improve on the livelihood of farmers. It was expected that about 70 tonnes of paddy rice from farmer fields would be purchased for quality improvement processing activity. The FSRPOP instituted a system to encourage farmers produce high quality rice by way of production contract and input credit as incentives. The primary objective of providing ready market for farmers' produce was achieved. However, some farmers refused to sell to the APEX; only a third of volume of paddy expected was sold. Apparently open market conditions at the time of harvest were better than anticipated based on the previous year's experience. Farmers actually expected the APEX to offer higher selling prices than the open market. Open market price for paddy rice was $\$ 16$ per $95 \mathrm{~kg}$ - bag as compared to $\$ 14$ per $83 \mathrm{~kg}$-bag offered by APEX. Generally farmers did not consider the weight of paddy per bag but rather 'bag' as the unit of measurement. Thus although the unit selling price (approximately $\$ 0.17 / \mathrm{kg}$ ) was the same for APEX and the open market farmers did not realized this as a problem of standardization. Table 1 gives a summary of farmers' constraints, proposed interventions, achievements and deviations identified.

\subsubsection{Processor}

At the processor level, the FSRPOP sought to provide technical assistance on best processing practices that would enhance rice quality. Two groups of processors from Tamale and Kumbugu benefited. Selected processors were indirectly linked up with participating farmers. The processors were given paddy rice organized from participating farmers by the APEX body for processing on service charge basis. Total service charge per 83-kg paddy bag for processing was US\$5.4 and US\$5.65 for Kumbugu and Tamale processors in the Northern region respectively. The difference in service charges was due to variations in processing costs.

Table 2 shows summary of processors constraints, interventions, achievements and deviations identified. The main challenges facing rice processors in the study area included inadequate access to quality raw material from farmers, inefficiencies in processing techniques, poor condition of drying space and inadequate access to urban market as well as low demand for local rice by the Ghanaian populace. The FSRPOP was therefore designed to improve access to quality raw material/paddy rice, provide technical assistance on best processing practices, and provide improved vessels which reduce fuel, water and labour costs and also make provision of cement for repair and maintenance of drying floors. The improved vessel has a higher capacity of parboiling one $83-\mathrm{kg}$ bag of paddy as compared to a third for the traditional pot. A total of 10 women processors benefited from the FSRPOP arrangement.

\subsubsection{Millers}

One of the factors affecting the quality of milled rice is the condition of the mill used. Two mills close to the location of processors were identified for rehabilitation under FSRPOP. These millers were supplied with shafts sieves, blades, bearings, belts and housing. The project management in collaboration with stakeholders and the APEX body estimated milling charge of US\$1.25 per $83-\mathrm{kg}$ parboiled paddy bag (milling passed twice) instead of existing milling charge of US\$1.0 (milling passed once). This was actually paid as expected. Table 3 shows summary of millers' constraints, proposed interventions and achievements.

\subsubsection{APEX}

Under the lowland Rice Development Project, it was identified that farmer based organizations in the study area were weak and unable to negotiate effectively with main stakeholders in the rice industry at the regional level. The FSRPOP aimed at building the capacity of the APEX body, which is the farmers' representative body at the regional level, to better serve the interest of farmers and also work effectively towards the achievement of the overall project goal of producing high quality parboiled-milled rice for an attractive market price. Table 4 shows summary of interventions, achievements and deviations identified at the APEX level.

\subsection{Perceptions about project performance}

\subsubsection{Farmers' perception}

Assessing the activities of the APEX body, about 75\% of the farmers visited in the project areas were quite satisfied with its capability with regards to helping farmers to access credit facility, inputs and tractor services (See figure 1). Individual farmers could not have had that opportunity. The rest (25\%) complained about delays on the part of the APEX body in assisting farmers to access inputs and tractor services. 
In relation to the marketing arrangements, half of the farmers did not have confidence in the capacity of the APEX body. Although majority of the farmers understood that whatever profit accruing from the quality improvement program was to be shared equitably among stakeholders, they felt the offer price for paddy at harvest was unattractive. Generally, farmers would want to store produce and sell when there are urgent needs for cash. This notwithstanding, farmers were willing to honour their contractual obligations if the price offer was attractive. Farmers also complained about the lack of communication on efforts being made by APEX to access urban market for parboiled and milled rice at the time of the survey.

\section{Sahakpaligu}

In the Sahakpaligu area, all the farmers $(100 \%)$ who participated in the project were happy with the APEX activities with respect to credit and input arrangements. Access to credit facilitated their planting activities more easily. The farmers also indicated that access to land preparation services as well as farming inputs especially fertilizer contributed immensely to the relatively high yields achieved. The average yield/acre ( 0.4 hectare) obtained by these farmers was 10 bags (a bag is $83-\mathrm{kg}$ paddy); minimum and maximum of 6 bags and 18 bags respectively.

Perception of this group on the marketing arrangements by the APEX body was fairly good. Although the buying price of paddy at US $\$ 14$ per $83-\mathrm{kg}$ bag offered by the Apex body was wrongly perceived to be a little lower than the average market price of US\$16 per $95 \mathrm{~kg}$-bag of paddy, the farmers sold off most of the paddy rice they had harvested to the Apex body. This is because they believed in the sustainability of the project as well as the terms of agreement of the project. Selling off the paddy to the Apex body made credit repayment easier. Extra sales made after deductions were perceived as profit since family labour was used. They also took into consideration the fact that transportation cost of conveying the paddy to the market was eliminated therefore making up for the difference in market price of the paddy compared to the price offered by the Apex body.

\section{Kumbunqu}

In this area the average yield per acre ( 0.4 hectare) of paddy rice harvested was approximately 10bags. Farmers in this area also perceived the project as being beneficial to them especially in terms of building the capacity of APEX to help farmers' access credit, inputs and tractor services. All the farmers in this area were contented because hitherto most of them could not afford to purchase basic farm inputs such as fertilizer for increased yield of their produce. They also expressed satisfaction at the training programmes they received under the project. Most of the farmers stated that training on the method of application of fertilizer was most beneficial to them since some of them lacked that requisite knowledge. On the whole this group was the most appreciative of the project and they expressed their willingness in sustaining its activities. They were known to be the group that sold off its entire rice paddy harvested to the Apex body. They had confidence in the marketing arrangement.

\section{Kuoku}

Farmers in this area indicated that though the project design was good and laudable in terms of building the capacity of the APEX to assist farmers' access credit, inputs and services for farming, poor climatic conditions coupled with unleveled fields prevented them from obtaining the full benefits of the project. Poor rainfall observed in this area during the planting period of the paddy rice was translated into low yields of approximately $7 \mathrm{bags} /$ acre of paddy rice harvested. The lowest yield in this area was 3 bags/acre $(0.4$ hectare $)$ and the highest was 11 bags/acre under the project. The farmers indicated that though yields gained under the project were low due to poor climatic conditions it was nonetheless superior to yield per acre for non-participating farmers. They were however not too happy with the marketing arrangements.

\section{$\underline{\text { Gbalahi }}$}

Farmers who participated in the programme in this area complained of some problems that did not make them realize the benefits of the project. They alleged that the credit, input and tractor service arrangements came a bit too late into the farming season. Hence the late cropping of the paddy rice resulted in low yields/acre of approximately 6.5 bags/acre. They maintained that normally yields could be as high as $18 \mathrm{bags} /$ acre $(0.4$ hectare). Farmers in this area were also not happy with the marketing arrangements offered by the APEX body. They hinted that the buying price of US\$14 per -bag of paddy proposed by the Apex body was too modest compared to the existing market value of US\$16 per -bag and therefore refused to sell any of the harvested rice to the APEX body. Farmers did not consider differences in weight of bagged rice sold (open market vis-à-vis offer by APEX body) and cost deduction for land preparation and inputs credit offered by APEX as per contract agreement.

\subsubsection{Perception of Processors}

All the two-processor groups interacted with gave positive outlook of the programme. Though initially unhappy about the service fee due to the relatively high cost of fuel, they were happy with upward adjustment of service fee from proposed US\$4.65 including milling charges to US\$5.4 - US\$5.65. Proposed margin/Man-day or labour cost of US\$2 per $83 \mathrm{~kg}$-bag was maintained. Processors were particularly impressed about the provision of improved vessels and 
cement for floor maintenance as already indicated. They however attributed relatively low quality of parboiled and milled rice to poor quality of paddy.

\subsubsection{Perception of Millers}

All the 2 millers involved in the project were happy about the performance of the APEX relating to decisions to rehabilitate milling facilities. They were also happy about the opportunity to review milling charges upwards for efficient milling services (milling passed twice to get clean rice). However how to sustain milling efficiency was a problem since milling twice added extra cost to the normal milling charges. Training on regular maintenance of milling facility was most beneficial to them.

\subsubsection{Perception of APEX}

Evaluating their performance, the farmer representatives were quick to point out that input supply arrangement was very effective and good for the farmers. They were also able to assist farmers to obtain inputs at relatively low prices. Loan transactions with the financial institutions were not smooth because a lot of time was spent on due diligence making sure only credit-worthy farmers participated in the programme. Again there were difficulties with paddy purchases since some farmers refused to sell or just sold enough to defray loan commitments. Only a third of expected volume of paddy was purchased. APEX members admitted that their organization was still young at the time of the survey. Administratively, it would have taken some time and a lot of education for them to become the strong organization expected. At the time of interview, APEX members were still not clear about the fate of parboiled and milled rice in stock while other stakeholders kept pestering them on profit sharing schemes when the milled rice was finally sold.

Generally, the APEX members were satisfied with rate of recovery obtained by processors. They claimed losses were more production related; due to immature and unfilled grains. This was caused by poor rains. Again some tarpaulins used for threshing were in pretty bad conditions. They perceived the project to be laudable however there were delays in credit release and field monitoring was not very effective due to lack of means of transport in certain occasions. At the processing level, quality improvement was below excellent. They claimed some of the rice had stones and black spots which might have been the result of poor quality paddy used.

The APEX body expressed their willingness to continue the programme but possibly with some modifications. From experience, they proposed limiting the programme to the farmer level. This meant that the APEX would assist farmers to access credit for input supplies that is deductible at harvest; farmers just selling off enough to defray loan commitments to processors.

\subsection{Gender Issues}

Women participation in the programme was rather low. Less than $10 \%$ of the farmers were females. This actually reflects representation of women in rice cropping. However all the 10 processors participating were females since rice processing is exclusively female activity

\section{Discussions}

\subsection{What went wrong?}

- $\quad$ Although the project participating farmers initially had problems with market access and therefore solicited for help at the beginning of the farming activities, these same farmers realized that they could get better prices in other market outlets. Market conditions changed in favour of the farmers due to low supply of local rice on the market in that particular year. Most stakeholders were not honest; some farmers did not declare their yields correctly and one group in Gbalahi failed to sell paddy to APEX body.

- $\quad$ Although farmers were given adequate extension training the quality of rice produced in some areas was low. Farmers failed to demonstrate that it is possible to obtain rice without black spots in the lowland. This could be due to irregular rainfall pattern, unleveled fields and deficient full water control.

- $\quad$ Processors had less recovery rates than expected; $59 \%$ instead of $62 \%$. Again because by the project design, processors were given paddy to process for a fee it was difficult monitoring their activities to ensure maximum processing recovery. It also became obvious that getting optimum processing recovery under field conditions could sometimes be difficult due to uncontrollable external factors. Technically, there are several factors affecting parboiling recovery rate and quality of parboiled rice. This includes quality of raw materials, moisture content of paddy, drying conditions and parboiling temperature among others (Marcelo et al 2004).

- $\quad$ APEX body was too weak in performing more complex administrative issues. Expectation that stakeholder representative (APEX), who were mostly from the rural communities set up under the project could penetrate the urban rice market was too high. Convincing urban dwellers to patronize local rice requires a lot of marketing skills and capacity. Effective promotion on the key selling points of locally produced and processed rice has to be undertaken. The project however did not have such mechanism and promotional strategy in place. 


\subsection{Emerging Issues}

Development of farmer based organizations is a major concern to both governments and development practitioners in developing countries. In Ghana, the Agricultural Services Sub sector Investment Project (AgSSIP) - 2000-2007 funded by the World Bank had a Farmer-Based Organisation (FBO) Development component. Efforts were made to strengthen the capacity of agencies promoting FBOs. Also under the on-going Millennium Challenge Account (MCA) project, the Private Enterprise Foundation with support from the Centre for International Private Enterprise (CIPE) based in Washington D.C., USA undertook an Advocacy Training Programme for Farmer-Based Organisations in some selected districts in Ghana (http://www.pefghana.org/mainsite/projects ).

Empirical evidence shows that strong Farmer-Based Organisations (FBOs) are able to access credit, farm inputs, extension services and markets effectively. However there are challenges with FBOs projects. The current study identified lack of innovation and market responsiveness, relatively low product quality and poor management of production contracts as some of the challenges faced by FBOs.

\subsubsection{Innovation and market responsiveness}

As explained in the introductory to this paper, market opportunities exist in the Ghanaian rice industry for enhanced production by smallholders farmers. However this increasingly depends on farmers' ability to compete in the rice market; yet there are many constraints (including high cost of production, lack of access to credit and inefficient markets for inputs among others) that make it difficult for them to do this. There is the need for more innovative production planning that is responsive to market requirements. In this study there was a problem with linking farmers to appropriate market outlets probably due to lack of information. Markelova et al 2008 suggested that collective action can help address some of the above-mentioned constraints. Farmers need to be well organised in order to take advantage of market opportunities. Work done in small-scale farm households in Honduras by Wollni et al (2008) also demonstrated that well coordinated farmer-based organization is crucial in addressing supply and demand challenges such as information deficiencies with respect to production processes, technology adoption and consumer preferences.

\subsubsection{Product quality}

Linked to the issue of market competitiveness is quality of local rice. The industrialization of the food system, including centralized and concentrated retail power, poses specific challenges for small farmers, especially those living in developing countries. Unless farmers are organized or operating very large farms, they cannot provide the reliable supply and quality required by new markets (Poulton et al 2006; Norman et al 2003). In Uganda for example, the rapid urbanization offers new market opportunities for smallholder farmers to supply higher value markets such as supermarket chains and fast-food restaurants. Supplying these formal outlets offers higher incomes but accessing and maintaining links to these markets requires significant upgrading in terms of product quality and business management. To meet these conditions farmers need to become more organised which require increased levels of social capital, to strengthen internal and external relations with group members, service providers and market chain actors.

Strong leadership and an iterative market-led learning process enabled a smallholder farmers' association to meet the considerable challenges of achieving the stringent quality parameters of a modern food outlet. As explained by von Braun (2006), the rice value chain is increasingly driven from its consumption and retail ends, rather than the production front. In effect, consumers' demand for higher quality rice and improved standards and regulations in the processing and marketing of rice are becoming more important.

\subsubsection{Management of production contract}

Contract farming can be defined as agricultural production carried out according to a prior agreement under which the farmer commits to producing a given product in a given manner, and the buyer commits to purchasing it at a given price (Minot and Hill 2007). Often the buyer provides the farmer with technical assistance, seed, fertilizer, and other inputs on credit, while offering a guaranteed price for the output. Proponents of contract farming argue that it links small-scale farmers to lucrative markets and reduces the constraints they face in diversifying into high-value commodities and connecting to markets.

Managing production contractual agreement with small-scale farmers posed a major challenge in the current study. In this case rice prices at the time of harvesting were above the contractual prices. Contract designs should therefore be able to capture price sensitivity analysis. Farmers just refused to respect their contractual obligations. Under the contract farmers had lost full autonomy over prices based on prevailing market conditions and product attributes at the time of sale. Contract enforcement has to be effective given the new role for contract farming in developing countries in the light of the industrialisation of agriculture and the globalisation of world markets (Kirsten and Sartorius 2002; Simmons, 2004). Masakure and Henson (2005) suggested that there are systematic differences between farmers in their decisions to contract which needs to be recognized in contract design and management. Contract farming can be facilitated by establishing an investment friendly policy environment, promoting public-private partnerships in extension, mediating disputes between farmers and buyers, and helping to enforce contracts. 


\section{Conclusions}

Performance of the APEX body was assessed satisfactory by $75 \%$ of the farmers interviewed. The APEX could enhance its capabilities through informal training on effective production and marketing planning. Regular training of FBOs on existing production and marketing arrangements and how to factor this in future predictions and planning activities is crucial. Production inputs arrangement by APEX must be timely to avoid unnecessary delays. Exploring the possibility of linking farmers to medium scale buyers could be a more effective marketing arrangement rather than targeting relatively smaller markets. Rice Inventory Credit System, where stocks are held in the harvest season for sale in the lean season could increase farmers' incomes.

At the farmer level, there is the need for transparency and all inclusive decision making at meetings so as to foster a common interest of all participating farmer groups. Improving the quality of rice starts right from the production stage, therefore best production practices have to be developed with farmers to facilitate adoption of such practices. Farmers need to play their roles by complying to contract regulations and rules agreed upon as a group. A group cohesion mechanism with adequate contract enforcement is crucial for sustainable rice farming.

Processors and millers also have responsibility towards improving the quality of local rice. Again best parboiling practices need to be developed with processors for effective adoption. It was also realized that custom based processing where processors buy improved paddy rice from farmers themselves for processing and then sell off to APEX after processing could serve as a better quality control mechanism. Millers should follow regular maintenance schedules in order to improve upon the milling efficiency.

Overall, the concept of farmer based organisation as a tool to consolidate farmers' strengthens and capabilities in sustainable rice farming was achieved to an appreciable extent. However it is concluded that farmer based organisations should not be burdened with administrative and marketing issues that are beyond their capabilities. Barham and Chitemi (2008) suggested that more mature groups with strong internal institutions, functioning group activities, and a good asset base of natural capital are more likely to improve their market situation.

\section{References}

Adolph, B., and T., Chancellor. (2006). Rice research in the DFID RNARRS Programmes. Lessons learnt and Implications for future research. Natural Resources Institute, University of Greenwich, UK.

Barham J and C., Chitemi. (2008). Collective action initiatives to improve marketing performance: Lessons from farmer groups in Tanzania. Science Direct Food Policy Article in press, Corrected proof, Accepted 2 October 2008.

Bello M., M.P., Tolaba and C. Suarez. (2004). Factors affecting water uptake of rice grain during soaking. Science Direct, Vol. 37, Issue 8, 2004.

Borgatti, S. P. (1999). Elicitation techniques for cultural domain analysis. Enhanced Ethnographic Methods: Audiovisual Techniques, Focused Group Interviews, and Elicitation Techniques, 3: 115-151. Ethnographer Toolkit, CA, Walnut Creek, Altamira.

Day, G. Oldham, P., Acheampong, J., Opoku-Apau and A., Langyintuo. (1997). Marketing of rice in Ghana- Improving the competitiveness of locally produced rice in Ghana, NRI; UK.

Denzin, N.K., \& Lincoln, Y.S. (2005). Introduction: The discipline and practice of qualitative research. In N. K. Denzin \& Y. S. Lincoln (Eds.), The Sage handbook of qualitative research (pp. 1-32). Thousand Oaks, CA: Sage.

Furuya, J., and T., Sakurai. (2003). Interlinkage in the rice market of Ghana: money-lending millers enhance efficiency. JIRCAS Research Highlights 2003. Japan International Research Centre for Agricultural Sciences.

Kaganzi, E., S., Ferris, J. Barham, A. Abenakyo, P. Sanginga and J. Njuki. (2008). Sustaining linkages to high value markets through collective action in Uganda. Science Direct, Accepted 2 October 2008

Khor, M. (2006). The impact of Globalization and liberalisation on Agriculture and small farmers in Developing Countries: The Experience of Ghana. Third World Network, [Online] Available: http://www.twnside.org.sg/title 2/par/Ghana (Accessed January 2009)

Kirsten J. and K. Sartorius. (2002). Linking agribusiness and small-scale farmers in developing countries: is there a new role for contract farming? Development Southern Africa, Vol. 19, Issue 4 October 2002, pages 503 - 529.

Markelova H, Meinzen-Dick R., Hellin J., and S Dohrn. (2008). Collective action for smallholder market access. Food Policy (Article in Press Accepted 2 October 2008).

Masakure O., and S., Henson. (2005). Why do small-scale producers choose to produce under contract? Lessons from nontraditional vegetable exports from Zimbabwe. World Development, Vol. 33, Issue 10, October 2005.

Minot N and R. V. Hill. (2007). Developing and Connecting Markets for Poor Farmers. 2020 Focus Brief on the World's Poor and Hungry People. Washington, DC: IFPRI. 
Murphy S. (2006). Concentrated Market Power and Agricultural Trade, A paper presented at ECOFAIR TRADE DIALOGUE. Discussion Paper No.1/August 2006 Washington, DC, United States.

Norman Clark, Andy Hall, Rasheed Sulaiman and Guru Naik (2003). Research as Capacity Building: The Case of an NGO Facilitated Post-Harvest Innovation System for the Himalayan Hills. World Development, Vol. 31, Issue 11, November 2003, Pages 1845-1863.

Nwanze, K.F., Mohapatra, S., Kormawa, P., Shellemiah, K,. and S. Bruce-Oliver. (2006). Rice Development in Sub-Sahara African. Journal of science of Food and Agriculture, Vol. 86:675-677.

Oteng J. W. (1997). Rice production and development in Ghana. International Rice Commission Newsletter, Vol. 46, pp. 38-43 FAO Rome.

Poulton C., Kydd J., and A., Dorward. (2006). Overcoming Market Constraints on Pro-Poor Agricultural Growth in Sub-Saharan Africa. Development Policy Review, Vol. 42 Issue 3. Pages 243 - 277.

Quaye W., P. Greenhalgh, J. T. Manful and L. Hammond. (2000). Rice Parboiling in Ghana, A Socio-Economic Survey. NRI Report No. 5577, Project R7543, Food Research Institute, Accra. (unpublished).

Quaye, W. (2007) Food Sovereignty and combating poverty and hunger in Ghana. Tailoring Biotechnogies, Vol 3, Issue 2; 101-108.

Simmons, P. (2004). Contract farming and village organisations: three case studies from Indonesia. ACIAR Technical Reports Series 2004, published by Australian Centre for International Agricultural Research (ACIAR).

Timsina J., H. Pathak, E. Humphreys, D. Godwin, B Singh, A.K., Shukla and U. Singh. (2004). Evaluation of, and yield gap analysis in rice using, CERES Rice Ver.4.0 in northwest India. Proceedings of the $4^{\text {th }}$ international crop science congress Brisbane, Australia, 26 Sep - 1 Oct 2004. [Online] Available: www.cropscience.org.au (Accessed January 2009).

Tomlins, K., Manful, J., Gayin, J., Kudjawu, B., and Tamakloe, I. (2007). Study of sensory evaluation, consumer acceptability, affordability and market price of rice. Journal of the science of food and Agriculture, Vol. 87:1564-1575

Tomlins, K., Manful, J., Larweh, P., and Hammond, L. (2005). Urban Consumer preference and sensory evaluation of locally produced and imported rice in West Africa. Food Quality and Preference, Vol. 16:79-89.

Von Braun J. (2006). Public Policy and international Collaboration for Sustaining and Expanding the Rice Revolution. International Food Policy Research Institute (IFPRI) Washington D.C., USA. [Online] Available: http://www.ifpri.org/pubs/speeches/2006 (Accessed January 2009).

Wollni, M; Lee, D. R., and J. E. Thies. (2008). Effects of participation in organic markets and farmer-based organizations on adoption of soil conservation practices among small-scale farmers in Honduras. A Paper provided by Agricultural and Applied Economics Association in its series 2008 Annual Meeting, July 27-29, 2008, Orlando, Florida. (Accessed January 2009). 


\section{APPENDIX 1}

\section{LIST OF ABBREVIATIONS}

\begin{tabular}{|l|l|}
\hline APEX & Representatives of Farmer based organisations \\
FSRPOP & Food Security and Rice Producers Organisation Project \\
FBOs & Farmer based organisations \\
MI & $\begin{array}{l}\text { Metric tons } \\
\text { NILRIFACU }\end{array}$ \\
LRDP & $\begin{array}{l}\text { Northern Region Intensive Lowland Rice Farmers Cooperative Union } \\
\text { SPSS }\end{array}$ \\
\hline
\end{tabular}




\section{APPENDIX 2}

\section{QUESTIONNAIRE GUIDE}

\section{APEX}

How was the APEX formed; selection of members/membership

Roles and responsibilities

Difficulties and challenges

Input supplier and credit management

Contract management

Marketing arrangement

\section{Farmers}

What are some of the constraints and Challenges you face in rice farming and how do you normally cope with them?

Were you involved in decisions on APEX formation and their responsibilities? if yes were you happy about the representation

Did you receive the following services as proposed with the project mangers?

- Technical assistance on best rice farming practices aimed at improving quality and yields

- Timely land preparation on credit

- $\quad$ Timely supply of production inputs on credit

- $\quad$ Ready market arrangement for paddy after harvesting

Did you go by the contract agreement by selling rice to APEX? If no give reasons

How would you describe you describe the performance of APEX body in carrying out their responsibilities stipulated in the Project Agreement? (Excellent, Satisfactory, or not satisfactory) Give reasons.

\section{Processors}

What are some of the constraints and Challenges you face in rice parboiling and how do you normally cope with them ?

Did you receive the following services as proposed with the project mangers?

- $\quad$ Access to quality raw material

- $\quad$ Provision of technical Assistance on best processing practices

- Provision of improved vessels which reduce fuel, water and labour costs

- $\quad$ Provision of cement for repair and maintenance of drying floors

- $\quad$ Payment for processing services

4. Millers

What are some of the constraints and Challenges you face in milling rice and how do you normally cope with them ?

Did you receive the following services as proposed by the project mangers?

- $\quad$ rehabilitation old rice milling facility by replacing shafts sieves, blades, bearings and belts

- $\quad$ construction of proper housing unit for rehabilitated rice mills 
Table 1. Summary of constraints, interventions, achievements and deviations at the farmer level

\begin{tabular}{|c|c|}
\hline $\begin{array}{l}\text { CONSTRAINTS } \\
\text { • Poor farming practices }\end{array}$ & $\begin{array}{l}\text { PROPOSED INTERVENTIONS } \\
\text { - Technical assistance on best rice } \\
\text { farming practices aimed at improving } \\
\text { quality and yields to about } 70 \text { farmers; } \\
\text { cultivating } 0.4 \text { hectare of rice farm each } \\
\text { - Timely land preparation on credit }\end{array}$ \\
\hline $\begin{array}{l}\text { - Late land preparation due to lack of } \\
\text { capital } \\
\text { - } \text { High cost of production inputs such as } \\
\text { seed and fertilizer } \\
\text { Lack of access to market, transportation } \\
\text { difficulties and unattractive selling } \\
\text { prices especially at harvest } \\
\text { No quality channel: no real incentive to } \\
\text { produce high quality rice }\end{array}$ & $\begin{array}{l}\text { - Timely supply of production inputs on } \\
\text { credit } \\
\text { - } \quad \text { Ready market arrangement for paddy } \\
\text { from farmers for quality improvement } \\
\text { processing activity }\end{array}$ \\
\hline $\begin{array}{l}\text { ACHIEVEMENTS } \\
\text { - Technical assistance on best rice } \\
\text { farming practices provided } \\
\text { - Input supply on credit (Agrochemical \& } \\
\text { improved seeds and fertilizers) provided }\end{array}$ & $\begin{array}{l}\text { DEVIATIONS } \\
\text { - Late programme start off } \\
\text { Low quality and low yields obtained in } \\
\text { irregular rainfall pattern, unleveled } \\
\text { field and its attendant problems with } \\
\text { water management } \\
\text { Some farmers refused to sell paddy to } \\
\text { APEX; only a third of expected volume } \\
\text { obtained due to relatively low shadow } \\
\text { prices }\end{array}$ \\
\hline
\end{tabular}


Table 2. Summary of interventions, achievements and deviations at the processor's level

\section{CONSTRAINTS}

- Inadequate access to quality raw material

- Inefficiencies in processing techniques

- Poor condition of drying space

- Inadequate access to urban market and low demand for local rice

\section{PROPOSED INTERVENTIONS}

- Access to quality raw material

- Provision of technical Assistance on best processing practices

- Provision of improved vessels which reduce fuel, water and labour costs

- Provision of cement for repair and maintenance of drying floors

- $\quad$ Payment for processing services

\section{ACHIEVEMENTS}

- Technical assistance on best rice processing practices and improved processing vessels were provided

- Cement was provided for maintenance of drying floors

- There was improvement in processing capacities without credit. The programme provided additional work and revenue to processors

\section{DEVIATIONS}

- Processors had access to raw material of relatively low quality

- Level of quality of parboiled rice lower than expected

- Recovery rate of parboiled rice lower than expected $(59 \%$ obtained instead of $62 \%$ expected). 
Table 3. Summary of miller's constraints, interventions and achievements

\begin{tabular}{|c|c|}
\hline $\begin{array}{l}\text { CONSTRAINTS } \\
\text { - Inefficient rice milling facilities } \\
\text { - Lack of proper housing } \\
\text { - Processors inability to pay realistic } \\
\text { milling fees for efficient milling services }\end{array}$ & $\begin{array}{l}\text { PROPOSED INTERVENTIONS } \\
\text { - To rehabilitation } 2 \text { old rice milling } \\
\text { facilities by replacing shafts sieves, } \\
\text { blades, bearings and belts } \\
\text { - To construct housing units for } \\
\text { rehabilitated rice mills } \\
\text { Estimated milling charge of US } \$ 1.25 \\
\text { per } 83-\mathrm{kg} \text { bag of parboiled rice paddy } \\
\text { (milling passed twice) proposed instead } \\
\text { of existing milling charge of US } \$ 1.0\end{array}$ \\
\hline $\begin{array}{l}\text { ACHIEVEMENTS } \\
\text { - Two rice milling facilities rehabilitated } \\
\text { (Shafts sieves, blades, bearings and belts } \\
\text { replaced for each mill) } \\
\text { - } \text { Housing unit constructed for each } \\
\text { rehabilitated mill } \\
\text { Milling charge of US } \$ 1.25 \text { per } 83-\mathrm{kg} \\
\text { bag of parboiled rice paddy paid by } \\
\text { APEX body }\end{array}$ & $\begin{array}{c}\text { DEVIATIONS } \\
\text { NIL }\end{array}$ \\
\hline
\end{tabular}


Table 4. Summary of interventions, achievements and deviations at the APEX level

\begin{tabular}{|c|c|}
\hline $\begin{array}{l}\text { CONSTRAINTS } \\
\text { Weak farmer based organization which was } \\
\text { unable to negotiate with main stakeholders at the } \\
\text { regional level }\end{array}$ & $\begin{array}{l}\text { PROPOSED INTERVENTION } \\
\text { Build the capacity of APEX to fulfill the following } \\
\text { functions } \\
\text { - Share information and build consensus between } \\
\text { cooperatives } \\
\text { - Organize access to inputs and tractor services } \\
\text { - Monitor cropping activities } \\
\text { - Manage and sustain their collective structures such } \\
\text { - Access and manage credit } \\
\text { - Access quality sensitive market }\end{array}$ \\
\hline $\begin{array}{l}\text { ACHIEVEMENTS } \\
\begin{array}{l}\text { - Input and services arrangement was } \\
\text { fairly good. } \\
\text { - Able to access and managed credit }\end{array}\end{array}$ & $\begin{array}{l}\text { DEVIATIONS } \\
\text { - APEX body was not strong enough to perform } \\
\text { administrative issues. Literacy level was woefully } \\
\text { inadequate. } \\
\text { - } \begin{array}{l}\text { Difficulty in enforcing contractual agreement with } \\
\text { farmers }\end{array} \\
\text { - Weak information sharing on the marketing } \\
\text { arrangements for parboiled and milled rice }\end{array}$ \\
\hline
\end{tabular}

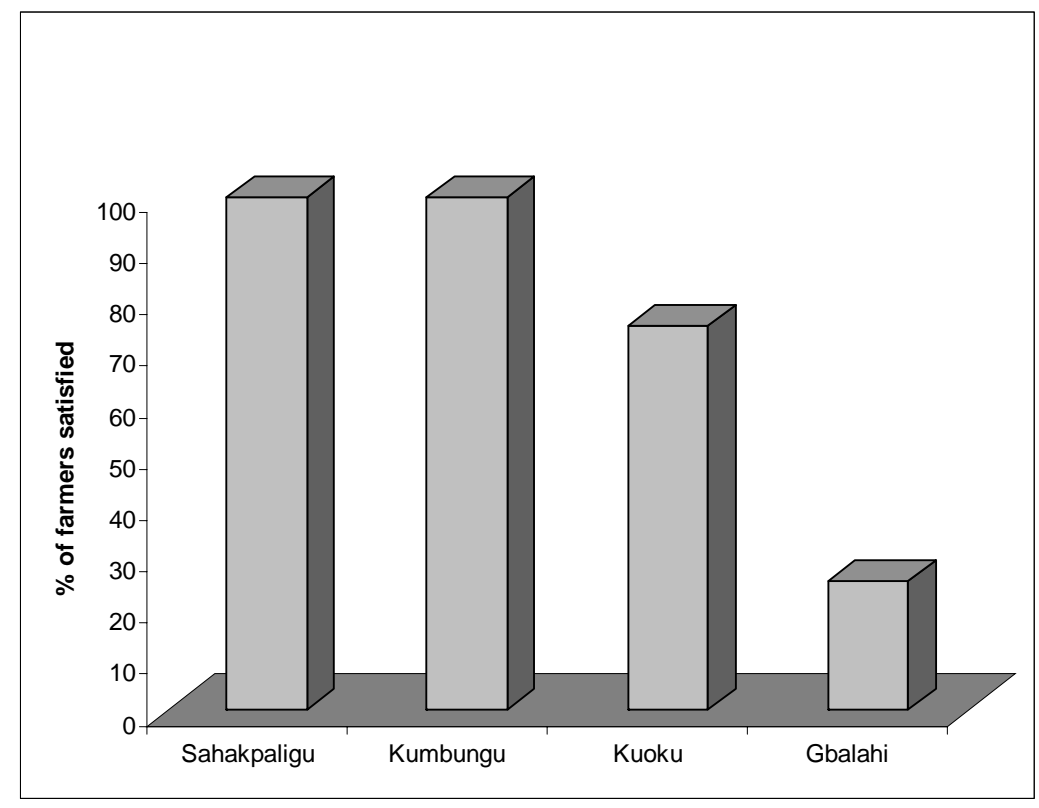

Figure 1. Farmers' satisfaction torwards APEX body performance in project participating communities 